Pak. j. sci. ind. res. Ser. A: phys. sci. 2017 60(2) 79-84

\title{
Dynamic Compression and Thermo-Physical Properties of Some Wood Particles in South Western Nigeria
}

\author{
Sunday Samuel Oluyamo ${ }^{\mathrm{a}}$, Mathew Adefusika Adekoya ${ }^{\mathrm{ab} *}$ and Olawale Ramon Bello ${ }^{\mathrm{a}}$ \\ ${ }^{a}$ Department of Physics, Federal University of Technology, Akure, Nigeria \\ ${ }^{\mathrm{b}}$ Department of Physics, Edo University, Iyamho, Edo State, Nigeria
}

(received June 6, 2016; revised January 10, 2017; accepted January 20, 2017)

\begin{abstract}
This study examines the dynamic compression and thermo-physical properties of some wood particles obtained from Akure, south local government area, Ondo State, South Western Nigeria. These wood particles are of the species of Celtis zenkeri and Celtis philippensis of the Ulmaceae family. The samples were possessed into different particle sizes $(300,600$ and $850 \mu \mathrm{m})$ and subjected to varied compacting pressures (2.6-3.0 MPa). The density and specific heat capacity of the wood samples were determined using weighing displacement methods and temperature dependent model while the thermal diffusivity was estimated from other thermal properties. The results revealed significant variation in the values of the specific heat capacity as a result of change in pressure for all the wood samples considered. The density of wood samples lies between $4.51 \times 10^{2}-7.32 \times 10^{2} \mathrm{~kg} / \mathrm{m}^{3}$ and the specific heat capacity values obtained for the samples fall within the range of $1.28 \times 10^{3}-1.33 \times 10^{3} \mathrm{~J} / \mathrm{kg} / \mathrm{K}$. It was also noted that the thermal diffusivity obtained falls within the range of $1.37 \times 10^{-7}-2.10 \times 10^{-7} \mathrm{~m}^{2} / \mathrm{s}$ for the wood materials considered. However, the values of the densities, specific heat capacities and thermal diffusivities of the samples were found to change as the compacting pressure increased due to decreased in porosity. The implication of the study is that the materials have potential for use in polymer applications and the fabrication of film based photographic devices.
\end{abstract}

Keywords: density, specific heat capacity, thermal diffusivity, wood particle

\section{Introduction}

Thermal insulation material generally reduces the heat flow by minimizing heat in a system. Thermal properties of a material include; thermal conductivity, thermal diffusivity and specific heat. It is of common knowledge that as the moisture content of a material increases, the thermal conductivity, thermal diffusivity and specific heat also increase (Ajit et al., 2013). One of the important parameters for determining the insulation property of a material is the specific heat capacity. It is the amount of heat required to raise the temperature of one kilogram of a material by one degree Kelvin. The specific heat capacity is fairly constant for different wood samples; it increases with temperature and moisture content (Simpson and Tenwolde, 1999). A high specific heat capacity value means high ability of heat retention for an insulating material (Ayugi et al., 2011). The thermal diffusivity $(\lambda)$ of a material is usually estimated from the values of the thermal conductivity $(k)$, density $(\rho)$ and specific heat capacity (c) (Moore, 2011; Glass and Zelinka, 2010; Silva et al., 1998; Suleiman et al., 1997). Thermal diffusivity is a measure of how quick a material

*Author for correspondence; E-mail: mathewadekoya14@gmail.com can absorb heat from its surroundings and diffused through crystal lattice of the material; it is the ratio of thermal conductivity to the product of density and heat capacity. Wood is a hard fibrous structural tissue found in the stems, roots of trees and other woody plants. It has been in use for many years as fuel (fire wood) and construction material. It is an organic material, a natural composite of cellulose fibres, embedded in a matrix of lignin which resists compression (Hickey and King, 2001). Sawdust is generally considered as a waste product. It is a by-product of wood, which is produced from sawing of wood (Badejo and Giwa, 1985). Saw dusts are very prevalent around sawmills and wood based industries (Akande, 2001). According to Ogunsawo (2001), the non-utilization of the sawdust create disposal problems, which are burdensome. Owonubi and Badejo (2000) have therefore observed that in order to dispose of the large environment and also cause environmental pollution; many saw miller resort to burning. It however produces smoke and offensive gases like carbon dioxide and carbon monoxide, which are hazardous to human health. Knowledge on the thermal properties of wood is a continuous process as the understanding of the model heat transfer processes in wood and wood based materials 
cannot be overemphasized. For example, the energy design and evaluation of energy performance of woodframe buildings partially rely on the thermal properties of wood and wood products (Zi-Tao et al., 2011; Tenwolde et al., 1988). Various properties had been adduced to affect the thermal properties materials which will in turn have attendant influence on their device utilization and applications (Oluyamo et al., 2016; Oluyamo and Adekoya, 2015; Oluyamo and Bello, 2014). This research intends to study the effect of dynamic compression on the thermo-physical properties of selected wood particles which may lead to a more beneficial usefulness to the society rather than menace.

\section{Materials and Methods}

Sample preparation. The wood materials used in the study are two different wood species growing in the rainforest region, South Western Nigeria. These species are; Celtis zenkeri and Celtis philippensis of the family Ulmaceae. The samples were collected from different sawmills in Akure, south local government area of ondo State, Nigeria. These wood samples were converted into sawdusts using circular saw machine and further separated into different particle sizes $(300,600$ and 850 $\mu \mathrm{m})$ with the aid of a mechanical test sieve shaker (Fig. 1). The samples were subjected to different compacting pressure (2.6-3.0 MPa) and later shaped into circular disc shape using a modified California Bearing Ratio (CBR). The preparation of the samples into disc shapes and particle sizes were carried out at the Department of Applied Geology and Material and Metallurgical Engineering Department of The Federal University of Technology, Akure. Possessed samples were oven dried in the laboratory before further analyses were carried out.

Determination of density and specific heat capacity. The density was measured for each of the sample using the weighing displacement methods (Akpabio et al., 2001; Ekpe et al., 1996) while Temperature Dependent Model (TDM) was used to determine the specific heat capacity of the wood samples. According to Simpson and Tenwolde (1999), the approximate specific heat capacity of oven-dry wood as a function of temperature is given as

where:

$$
\mathrm{c}=0.1031+0.003867 T
$$

$T$ is the equilibrium temperature.

Determination of Thermal Diffusivity. The thermal diffusivity is given as

$$
\lambda=\frac{\mathrm{k}}{\rho \mathrm{c}}
$$

The thermal conductivity of the two samples at different compacting pressure and particle sizes has earlier been reported by Oluyamo and Adekoya (2015).

\section{Results and Discussion}

Density. Variation in densities of the samples has been depicted in Fig. 2-3. The values of the density were

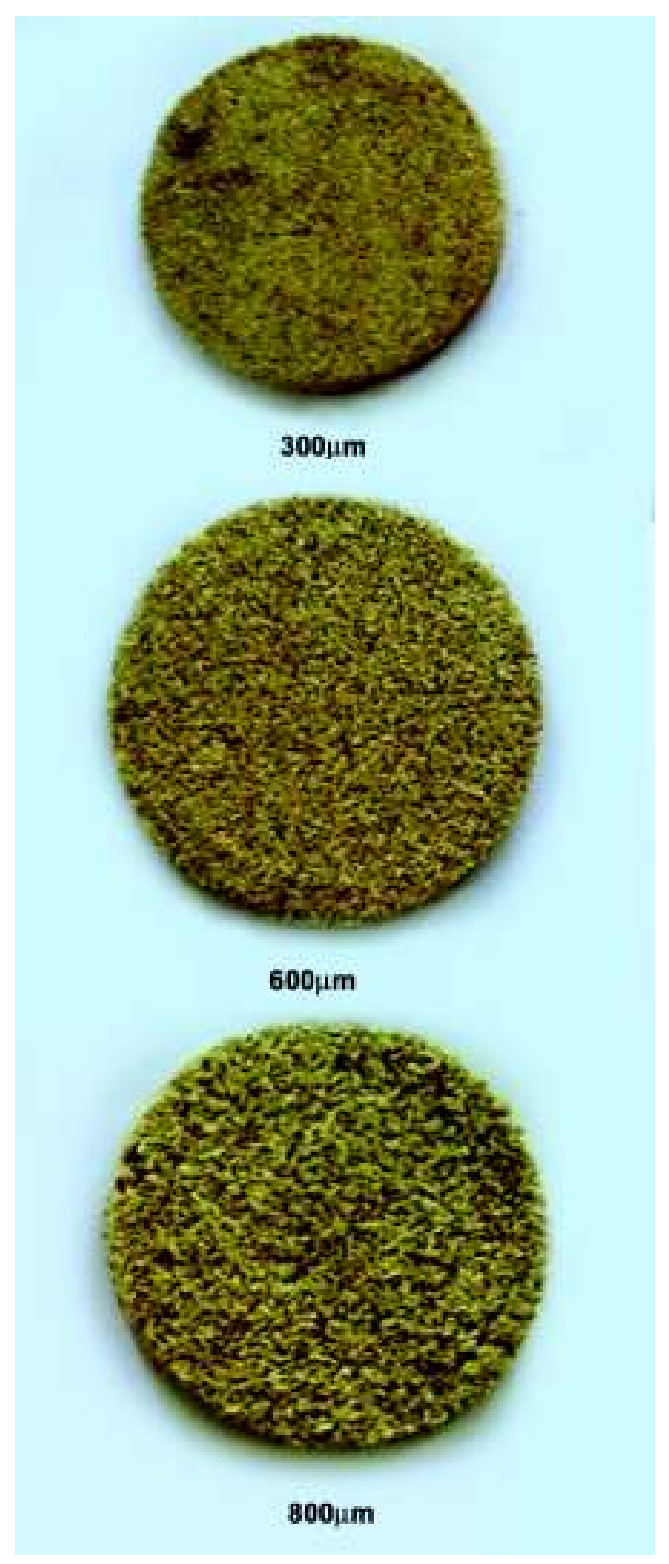

Fig. 1. Final disc shape of the samples for different particle sizes. 
found to change as the compacting pressure increased. There also seems to be no definite variation in densities of the material with compacting pressure. However, for C. zenkeri, the densities of the wood samples increases as the particle sizes decreases except at 3.0 MPa.

These values of densities of wood samples for different compacting pressures at particle sizes, 300, 600 and $850 \mu \mathrm{m}$, respectively are shown in Tables $1-2$. The values of the density ranged from $4.51 \times 10^{2}-6.81 \times 10^{2}$ $\mathrm{kg} / \mathrm{m}^{3}$ for C. philippensis (Ita funfun) and $4.7 \times 10^{2}$ $7.32 \times 10^{2} \mathrm{~kg} / \mathrm{m}^{3}$ for $C$. zenkeri (Ita pupa). The values of the densities were found to be relatively high for $300 \mu \mathrm{m}$ particle size at $2.7 \mathrm{MPa}$ compacting pressure for $C$. zenkeri.

Specific heat capacity. The variations of the various specific heat capacities of the selected wood samples as a function of compacting pressure are displayed in

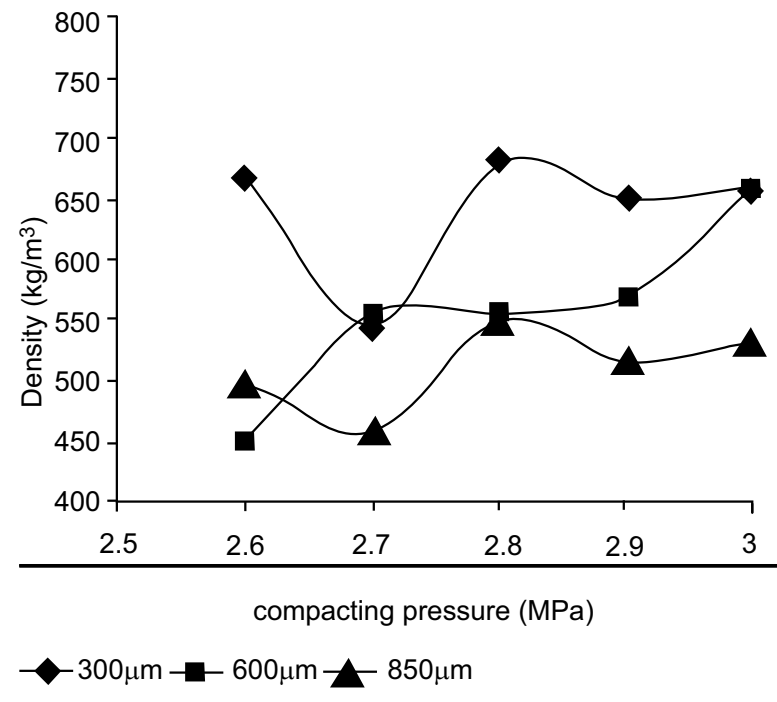

Fig. 2. Graph of density as a function of compacting pressure for Celtis philippensis (Ita funfun).

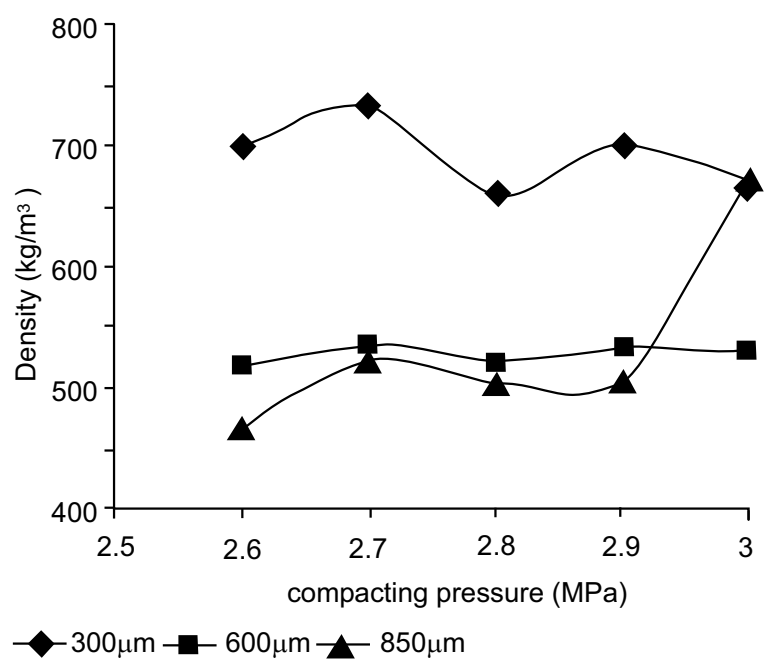

Fig. 3. Graph of density as a function of compacting pressure for Celtis zenkeri (Ita pupa).

Fig. 4-5. It was observed that the specific heat capacity has no defined trend with the compacting pressure for all the wood samples. The values of the specific heat capacities only fluctuate between minimum and maximum values within the range of compacting pressure.

The specific heat capacities of the wood samples depend on the moisture content of the wood and seen to be independent of density and species which is in agreement with previous research (Simpson and Tenwolde, 1999). In addition, materials with high specific heat capacity absorb more energy before they change in temperature than substances with low specific heat capacity (Oladunjoye and Sanuade, 2012; Oyekan and Kamiyo, 2011). The specific heat capacity values obtained ranged between $1.29 \times 10^{3}-1.33 \times 10^{3} \mathrm{~J} / \mathrm{kg} / \mathrm{K}$ for $C$. phillipensis and $1.28 \times 10^{3}-1.31 \times 10^{3} \mathrm{~J} / \mathrm{kg} / \mathrm{K}$ for C. zenkeri. The samples have their highest specific heat capacity at 300 $\mu \mathrm{m}$ particle size of $3.0 \mathrm{MPa}$ with C. philippensis having

Table 1. Thermal Properties of Celtis philippensis

\begin{tabular}{|c|c|c|c|c|c|c|c|c|c|}
\hline \multirow{2}{*}{$\begin{array}{l}\text { Compacting } \\
\text { pressure } \\
(\mathrm{MPa})\end{array}$} & \multicolumn{3}{|c|}{$\begin{array}{l}\text { Density } \\
\left(10^{2} \times \mathrm{kg} / \mathrm{m}^{3}\right)\end{array}$} & \multicolumn{3}{|c|}{$\begin{array}{l}\text { Specific heat capacity } \\
\left(10^{3} \times \mathrm{J} / \mathrm{kg} / \mathrm{K}\right)\end{array}$} & \multicolumn{3}{|c|}{$\begin{array}{l}\text { Thermal diffusivity } \\
\left(10^{-7} \times \mathrm{m}^{2} / \mathrm{s}\right)\end{array}$} \\
\hline & $300 \mu \mathrm{m}$ & $600 \mu \mathrm{m}$ & $850 \mu \mathrm{m}$ & $300 \mu \mathrm{m}$ & $600 \mu \mathrm{m}$ & $850 \mu \mathrm{m}$ & $300 \mu \mathrm{m}$ & $600 \mu \mathrm{m}$ & $850 \mu \mathrm{m}$ \\
\hline 2.6 & 6.70 & 4.51 & 4.99 & 1.29 & 1.31 & 1.30 & 1.54 & 2.10 & 1.86 \\
\hline 2.7 & 5.45 & 5.55 & 4.60 & 1.31 & 1.30 & 1.30 & 2.00 & 1.85 & 2.05 \\
\hline 2.8 & 6.81 & 5.58 & 5.50 & 1.29 & 1.30 & 1.30 & 1.72 & 1.93 & 1.77 \\
\hline 2.9 & 6.51 & 5.70 & 5.18 & 1.31 & 1.30 & 1.30 & 1.77 & 1.91 & 1.93 \\
\hline 3.0 & 6.58 & 6.58 & 5.31 & 1.33 & 1.30 & 1.30 & 1.75 & 1.68 & 1.96 \\
\hline
\end{tabular}


Table 2. Thermal properties of Celtis zenkeri

\begin{tabular}{|c|c|c|c|c|c|c|c|c|c|}
\hline \multirow{2}{*}{$\begin{array}{l}\text { Compacting } \\
\text { pressure } \\
(\mathrm{MPa})\end{array}$} & \multicolumn{3}{|c|}{$\begin{array}{l}\text { Density } \\
\left(10^{2} \times \mathrm{kg} / \mathrm{m}^{3}\right)\end{array}$} & \multicolumn{3}{|c|}{$\begin{array}{l}\text { Specific Heat Capacity } \\
\left(10^{3} \times \mathrm{J} / \mathrm{kg} / \mathrm{K}\right)\end{array}$} & \multicolumn{3}{|c|}{$\begin{array}{l}\text { Thermal Diffusivity } \\
\left(10^{-7} \times \mathrm{m}^{2} / \mathrm{s}\right)\end{array}$} \\
\hline & $300 \mu \mathrm{m}$ & $600 \mu \mathrm{m}$ & $850 \mu \mathrm{m}$ & $300 \mu \mathrm{m}$ & $600 \mu \mathrm{m}$ & $850 \mu \mathrm{m}$ & $300 \mu \mathrm{m}$ & $600 \mu \mathrm{m}$ & $850 \mu \mathrm{m}$ \\
\hline 2.6 & 7.00 & 5.20 & 4.70 & 1.30 & 1.29 & 1.30 & 1.37 & 1.68 & 1.66 \\
\hline 2.7 & 7.32 & 5.36 & 5.23 & 1.31 & 1.30 & 1.29 & 1.38 & 1.70 & 1.67 \\
\hline 2.8 & 6.60 & 5.23 & 5.05 & 1.30 & 1.30 & 1.31 & 1.58 & 1.82 & 1.74 \\
\hline 2.9 & 7.00 & 5.33 & 5.08 & 1.29 & 1.28 & 1.30 & 1.56 & 1.93 & 1.80 \\
\hline 3.0 & 7.00 & 5.30 & 6.75 & 1.30 & 1.31 & 1.30 & 1.70 & 1.97 & 1.42 \\
\hline
\end{tabular}

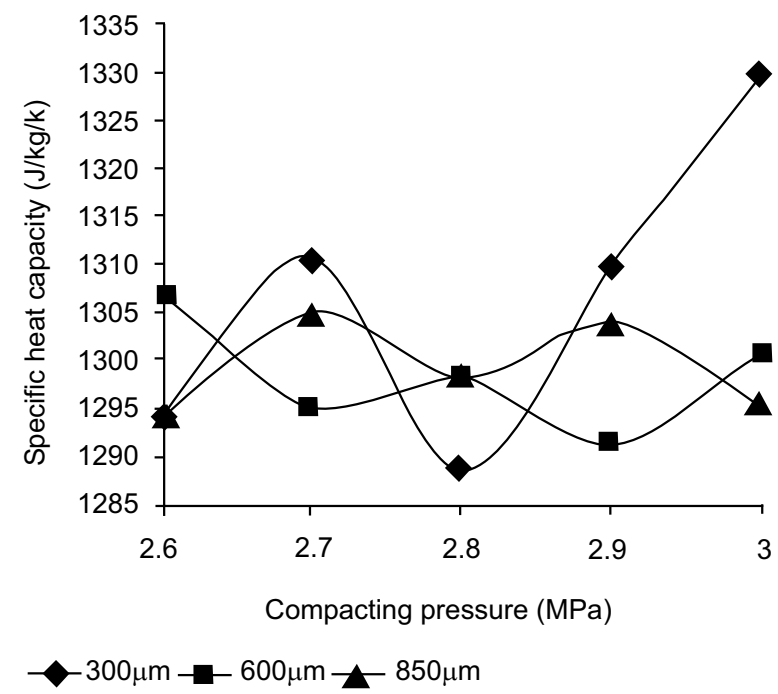

Fig. 4. Graph of specific heat capacity as a function of compacting pressure for Celtis philippensis (Ita funfun).

the highest specific heat capacity value of $1.33 \times 10^{3}$ while $C$. zenkeri has the least for $600 \mu \mathrm{m}$ particle sizes at 2.9 MPa. These values are within the range obtained by Simpson and Tenwolde (1999) and the values conform to Kärkkäinen (2007) which is $1.34 \times 10^{3} \mathrm{~J} / \mathrm{kg} / \mathrm{K}$ at temperature range of $273-373 \mathrm{~K}$. The results of the study reveals that the specific heat capacity values conform to common material used in polystyrene $\left(1.30 \times 10^{3}-1.50 \times 10^{3}\right)$, polycarbonates $\left(1.20 \times 10^{3}\right.$ $\left.1.30 \times 10^{3}\right)$ and cellulose acetate $\left(1.30 \times 10^{3}-1.80 \times 10^{3}\right)$ (www.engineering tool box.com, May 2016). Therefore, the particulate materials could be useful in the fabrication of film based photography, eye protection, producing plastics cutlery and dinnerware and smoke detector housing. However, the particle sizes seem to be more suitable in these categories

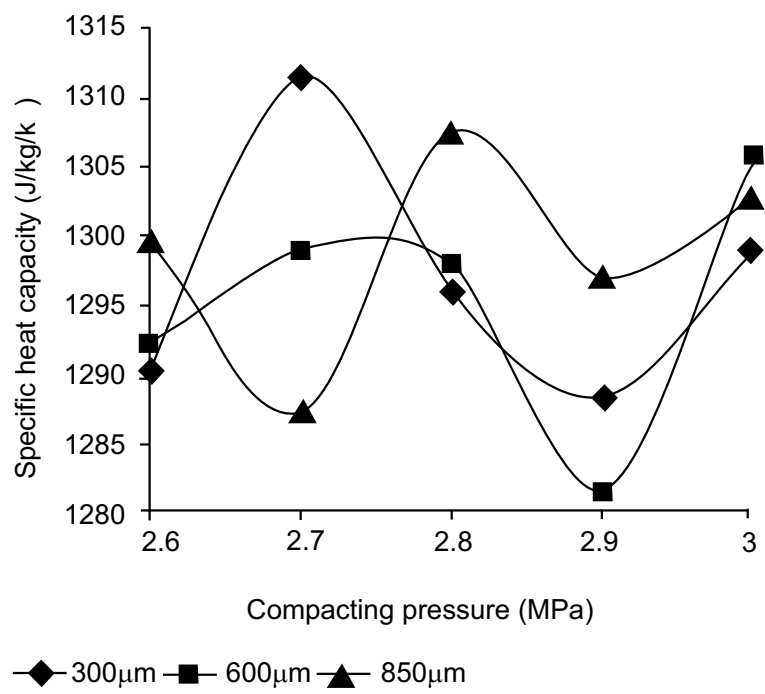

Fig. 5. Graph of specific heat capacity as a function of compacting pressure for Celtis zenkeri (Ita pupa).

Thermal Diffusivity. Variations of thermal diffusivities of the selected wood samples are depicted in Fig. 6-7. The values of the thermal diffusivity change gradually as the compacting pressure increases except at $2.9 \mathrm{MPa}$ compacting pressure which increases as the particle sizes increase.

Evidence of slight increase in thermal diffusivities of the wood samples was noticed as particle size increases from $300 \mu \mathrm{m}$ to $600 \mu \mathrm{m}$ but decreases monotonically at $850 \mu \mathrm{m}$ for $c$. zenkeri.

\section{Conclusion}

The effects of dynamic compression on thermal properties of wood species were investigated. It was established in the research that the specific heat capacity 


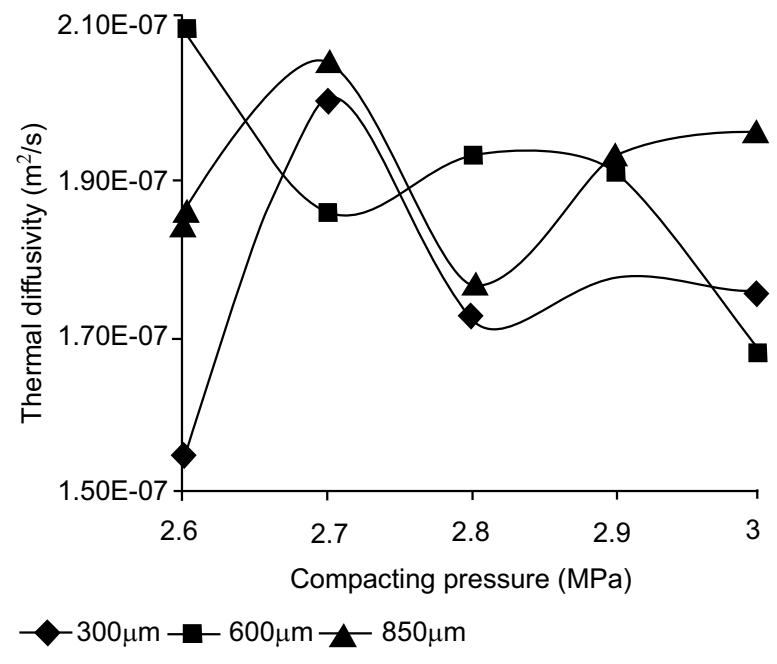

Fig. 6. Graph of thermal diffusivity as a function of compacting pressure for Celtis philippensis (Ita funfun).

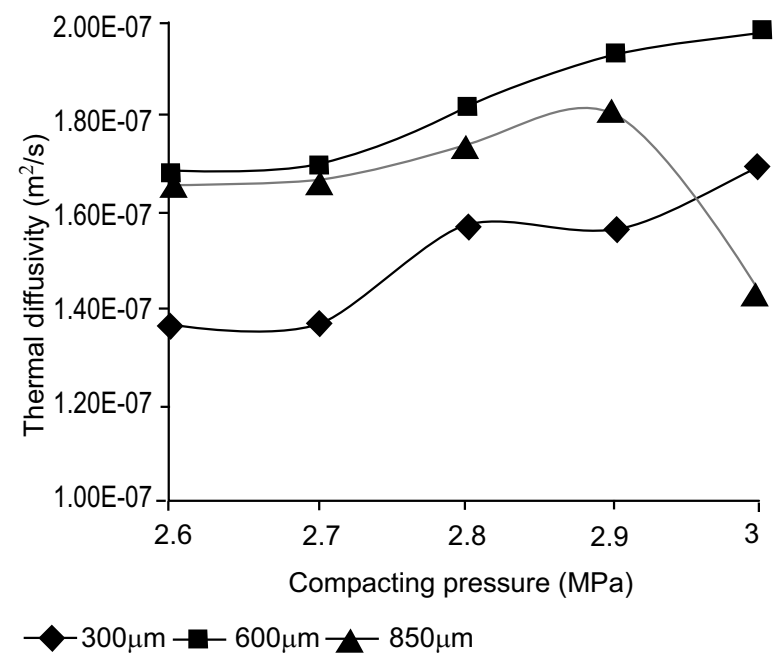

Fig. 7. Graph of thermal diffusivity as a function of Compacting Pressure for Celtis zenkeri (Ita pupa).

of wood materials used in the study falls between $1.28 \times 10^{3}-1.33 \times 10^{3}$. This range lies within the specific heat capacity values of common materials used in polystyrene, polycarbonates and cellulose acetate. The selected wood materials could find useful applications in insulating and heat resistant devices. The results in the study revealed that compacting pressure and density has an effect on the thermal diffusivities but has no significant effect on specific heat capacity of the wood samples studied.

\section{References}

Ajit, K. M., Shetelia, L. M., Edwin, M. I. 2013. Effect of moisture content on thermal properties of cowpea flours. Agricultural Engineering International: CIGR Journal, 15: 251-255

Akande, J. A. 2001. Briquetting Sawdust and Low Density Coal For Sustainable Livelihood. Proceeding of the $28^{\text {th }}$ Annual Conference of Forestry Association of Nigeria, AKURE, $4^{\text {th }}-8^{\text {th }}$ Nov. pp. 127-137.

Akpabio, L. E., Ekpe, S. D., Etuk, S. E., Essien, K. E. 2001. Thermal properties of oil and Raffia palm fibres. Global Journal of Pure and Applied Science, 7: 575-578.

Ayugi, G., Banda, E.J.K.B., D’Ujanga, F.M. 2011. Local thermal insulating materials for thermal energy storage. Rwanda Journal, 23: 21-29.

Badejo, S.O., Giwa, S. A. 1985. Volume Assessment and Economic Importance of Sawmill Wood Waste Utilization in Nigeria. Technical Report No 50. Forestry Research Institution of Nigeria. Ibadan, Nigeria.

Ekpe, S.D., Akpabio, L. E., Eno, E .E. 1996. Thermal properties of soil samples in Uyo local government area of Akwa Ibom State of Nigeria. Global Journal of Pure and Applied Science, 2: 45-52.

Glass, V.S., Zelinka, S. L. 2010. Moisture Relations and Physical Properties, In: Wood Handbook- Wood as an Engineering Material. USDA Forest Service, pp. 10-12, 100th edition, Madison, WI, USA,

Hickey, M., King, C. 2001. The Cambridge Illustrated Glossary of Botanical Terms. Cambridge University Press, UK.

Kärkkäinen, M. 2007. Puun rakenne ja ominaisuudet. Hämeenlinna. Karisto Oy. pp. 468

Moore, J. 2011. World Properties and Uses of Sitka Spruce in Britain. Forest Commission Research Report, pp. 17-20, Edinburgh, Scotland, UK.

Oladunjoye, M. A., Sanuade, O. A. 2012. Thermal diffusivity, thermal effusivity and specific heat capacity of soils in Olorunsogo Power Plant, Southwestern Nigeria. International Journal of Research and Reviews in Applied Science, 13: 502521.

Ogunsanwo, O. Y. 2001. Effective Management of Wood Wastes for Sustainable Wood Utilization in Nigeria. Proceeding of the $27^{\text {th }}$ Annual Conference of Forestry Association of Nigeria, Akure, 17th$21^{\text {th }}$ Sept. pp. 127-137.

Oluyamo, S.S., Famutimi, O.F., Adekoya, M. A., 
Aramide, T. A. 2016. Thermal properties of soil samples from coastal sand landform in Ilaje local government area of Ondo State, Nigeria. Journal of Advances in Physics, 11: 4137- 4140.

Oluyamo, S.S., Adekoya, M. A. 2015. Effects of dynamic compression on the thermal conductivities of selected wood products of different particle sizes. International Research Journal of Pure and Applied Physics, 3: 22-29.

Oluyamo, S.S., Bello, O.R. 2014. Particle sizes and thermal insulation properties of selected wood materials for solar device application. Journal of Applied Physics, 6: 54-58.

Owonubi, J. J., Badejo, S.O. 2000. Industrial Scale Wood Waste Conversion into Building Materials at FRIN, Ibadan. A paper presented at the $\mathbf{3 8}^{\text {th }}$ Annual Conference of Science Association of Nigeria. $10^{\text {th }}-14^{\text {th }}$ December.

Oyekan, G. I., Kamiyo, M. O. 2011. A study on the engineering properties of sandcrete block produced with rice husk as blended cement. Journal of Engineering and Tech Research, 3: 88-98.

Silva, T.S., Alves, A.S., Pepe, U., Tsuzuki, H., Nakamura,
O., Aguitar, M. M., Neto, F., An, A.Y., Ferreira, A.,Veissid, N. 1998. Thermal diffusivity of lead iodide. Journal of Applied Physics, 83: 6193-6195. Simpson, W., TenWolde, A. 1999. Physical Properties and Moisture Relations of Wood In: Wood Handbook: Wood as an Engineering Material. pp. 15-22, Forest Service, Forest Products Laboratory, Madison, USA.

Suleiman, B.M., Gustavsson, M., Karawachi, E., Lunden, A.I. 1997. Thermal properties of lithium sulphate. Journal of Physics, 30: 2553-2560.

TenWolde, A., McNatt, J. D., Krahn, L. 1988. Thermal Properties of Wood and Wood Panel Products for Use in Buildings. Oak Ridge National Laboratory, Oak Ridge, Tennessee, U.S, pp 39.

Zi-Tao, Y ., Xu, X., Li-Wu, F., Ya-Cai, H., Ke-Fa, C. 2011. Experimental measurements of thermal conductivity of wood species in China: Effects of density, temperature, and moisture content. Forest Products Journal, 61: 130-135.

www. engineering tool box.com (May 2016). Resources, Tools and Basic Information for Engineering and Design of Technical Applications. 